\title{
GROUND-WATER RESOURCES FOR THE FUTURE
}

\section{Land Subsidence in the United States}

Ground water is among the Nation's most important natural resources. It provides drinking water to urban and rural communities, supports irrigation and industry, sustains the flow of streams and rivers, and maintains riparian and wetland ecosystems. In many areas of the Nation, the future sustainability of ground-water resources is at risk from overuse and contamination. Because ground-water systems typically respond slowly to human actions, a long-term perspective is needed to manage this valuable resource. This publication is one in a series of fact sheets that describe ground-waterresource issues across the United States, as well as some of the activities of the U.S. Geological Survey that provide information to help others develop, manage, and protect ground-water resources in a sustainable manner.

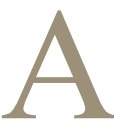
recent U.S. Geological Survey (USGS) report (Galloway and others, 1999) shows that sustainable development of our land and water resources depends on improved scientific understanding and detection of subsidence. The report features nine illustrative case studies that demonstrate the role of subsurface water in human-induced land subsidence (http:// water.usgs.gov/ pubs/circ/circ1182). More than 80 percent of the identified subsidence in the United States is a consequence of human impact

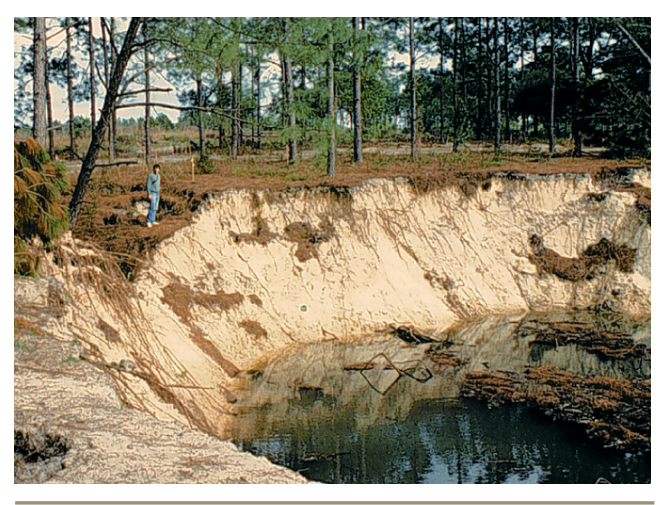

Figure 1. Development of a new irrigation well in west-central Florida triggered hundreds of sinkholes over a 20-acre area. The sinkholes ranged in size from less than 1 foot to more than 150 feet in diameter.
Subsidence is a global problem and, in the United States, more than 17,000 square miles in 45 States, an area roughly the size of New Hampshire and Vermont combined, have been directly affected by subsidence. The principal causes are aquifersystem compaction, drainage of organic soils, underground mining, hydrocompaction, natural compaction, sinkholes, and thawing permafrost (National Research Council, 1991). Three distinct processes account for most of the water-related subsidence - compaction of aquifer systems, drainage on subsurface water, and is an often overlooked environmental consequence of our land and water-use practices. The increasing development of our land and water resources threatens to exacerbate existing land-subsidence problems and initiate new ones (fig.1).

Land subsidence is a gradual settling or sudden sinking of the Earth's surface owing to subsurface movement of earth materials. and subsequent oxidation of organic soils, and dissolution and collapse of susceptible rocks.

Figure 2. Approximate location of maximum subsidence in the United States identified by research efforts of Dr. Joseph F. Poland (pictured). Signs on pole show approximate altitude of land surface in 1925, 1955, and 1977. The site is in the San Joaquin Valley southwest of Mendota, California.

\section{Mining Ground Water}

The compaction of unconsolidated aquifer systems that can accompany excessive ground-water pumping is by far the single largest cause of subsidence. The overdraft of such aquifer systems has resulted in permanent subsidence and related ground failures. In aquifer systems that include semiconsolidated silt and clay layers (aquitards) of sufficient aggregate thickness, long-term ground-water-level declines can result in a vast one-time release of "water of compaction" from compacting aquitards, which manifests itself as land subsidence (fig. 2). Accompanying this release of water is a largely nonrecoverable reduction in the pore volume of the compacted aquitards, and thus a reduction in the total storage capacity of the aquifer system. This "water

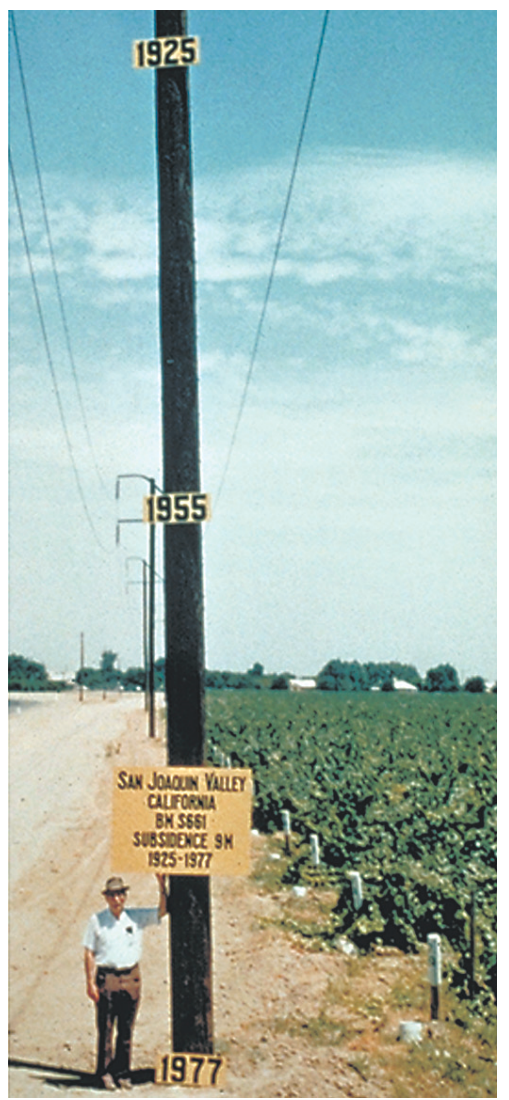




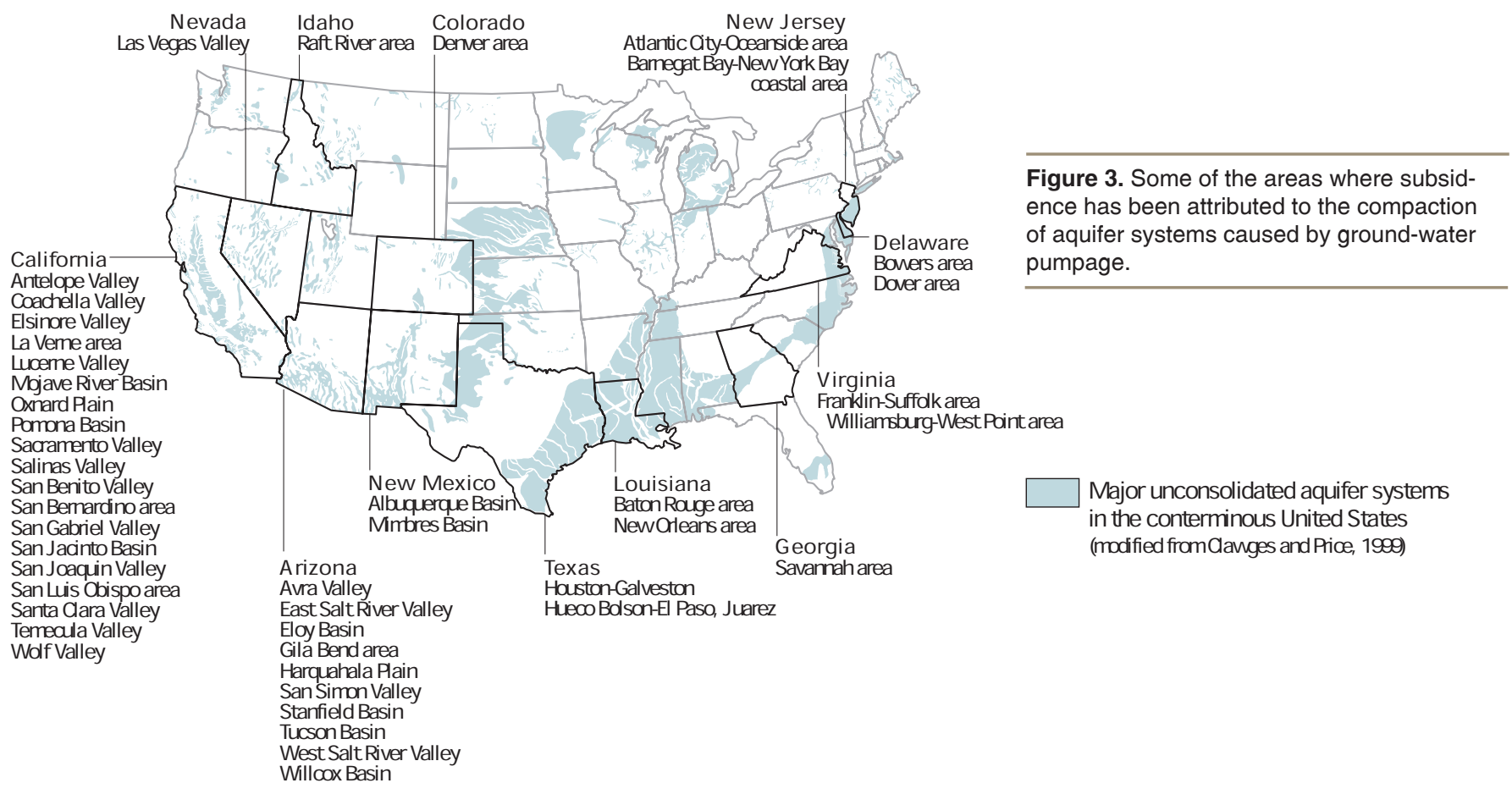

of compaction" cannot be reinstated by allowing water levels to recover to their predevelopment status. The extraction of this resource for economic gain constitutes "ground-water mining" in the truest sense of the term.

Five case studies demonstrate how agricultural and municipal-industrial ground-water use have depleted critical ground-water resources and created costly regional-scale subsidence (fig. 3). These include the Santa Clara Valley in northern California, where early agricultural ground-water use contributed

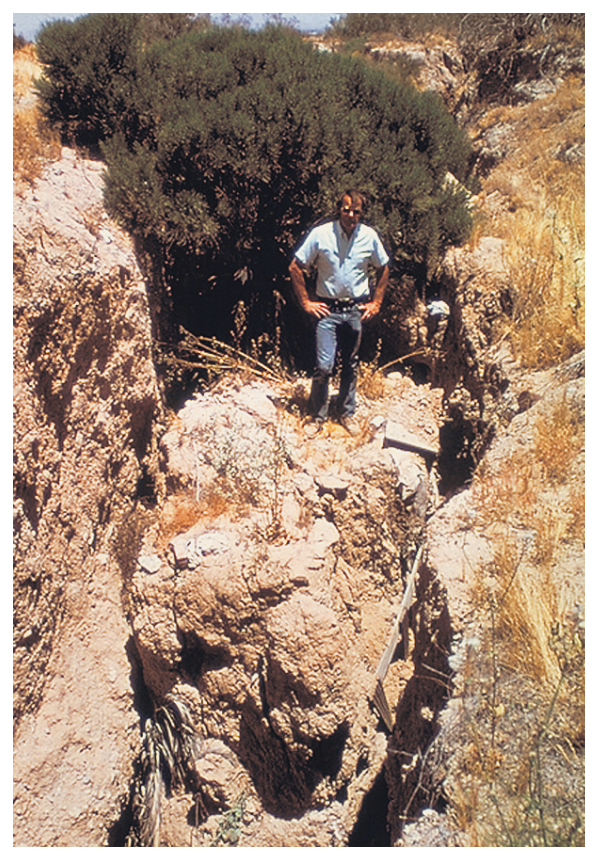

to subsidence that has permanently increased flood risks in the greater San Jose area. In nearby San Joaquin Valley, one of the single largest human alterations of the Earth's surface topography has resulted from excessive groundwater pumpage to sustain an exceptionally productive agriculture (fig. 2). The banner photo (front page, top) shows the California Aqueduct coarsing through the San Joaquin Valley. The aqueduct conveys water from the Sacramento-San Joaquin Delta to basins affected by subsidence in central and southern California. Early oil and gas production and a long history of ground-water pumpage in the Houston-Galveston area, Texas, have created severe and costly coastal-flooding hazards and affected a critical environmental resource - the Galveston Bay estuary (fig. 4). In Las Vegas Valley, Nevada, ground-water depletion and associated subsidence have accompanied the conversion of a desert oasis into a thirsty and fast-growing metropolis. Waterintensive agricultural practices in southcentral Arizona caused wide-spread subsidence and fissuring of the Earth's surface (fig. 5). In each of these areas, however, importation of surface water has reduced or stabilized ground-water

Figure 5. Some of the most spectacular examples of subsidence-related earth fissures occur in south-central Arizona.

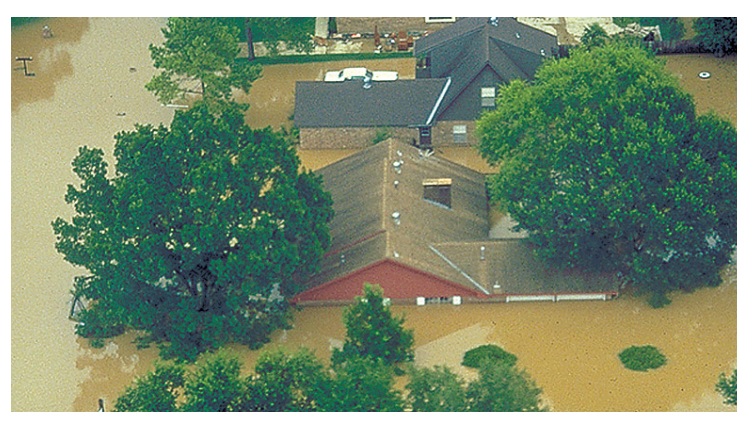

Figure 4. Homes at Greens Bayou near Houston, Texas, where 5 to 7 feet of subsidence has occurred, were flooded during a storm in June 1989.

pumpage, thereby halting or slowing subsidence, at least temporarily.

\section{Drainage of Organic Soils}

Land subsidence invariably occurs when soils rich in organic carbon are drained for agriculture or other purposes. The most important cause of this subsidence is microbial decomposition, which, under drained conditions, readily converts organic carbon to carbon-dioxide gas and water. Compaction, desiccation, erosion by wind and water, and prescribed or accidental burning can also be significant factors.

The total area of organic soils in the United States is roughly equivalent to the size of Minnesota, about 80,000 square miles, nearly half of which is "moss peat" located in Alaska (Lucas, 1982) (fig. 6). About 70 percent of the organic-soil area 


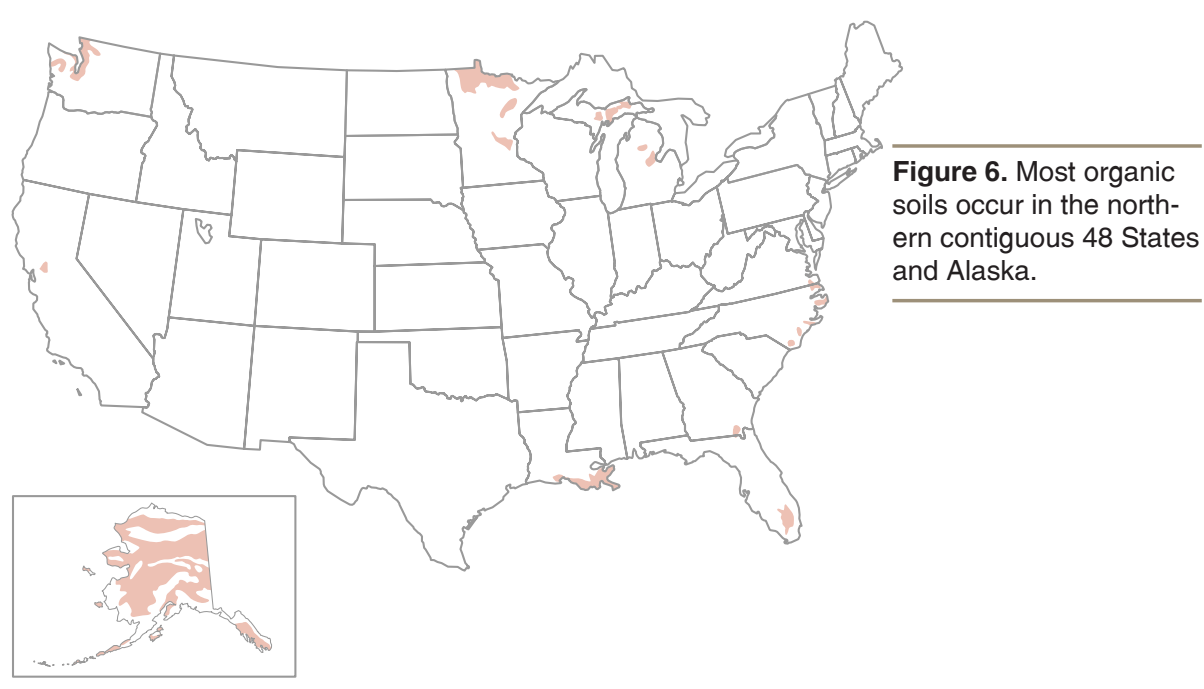

in the contiguous 48 states occurs in northerly, formerly glaciated areas, where moss peats are also common (Stephens and others, 1984). Moss peat is composed mainly of sphagnum moss and associated species. It is generally very acidic $(\mathrm{pH} 3.5$ to 4 ) and, therefore, not readily decomposed, even when drained. However, where moss peat is amended for agricultural cultivation, for example through fertilization and heavy application of lime to raise the $\mathrm{pH}$, it can decompose nearly as rapidly as other types of organic soils.

Two case studies of organic-soil subsidence focus on examples of rapid subsidence (1 to 3 inches/year) caused by decomposition of the remains of shallow-water sedges and reeds. In two of the Nation's important wetland ecosystems - the Sacramento-San Joaquin

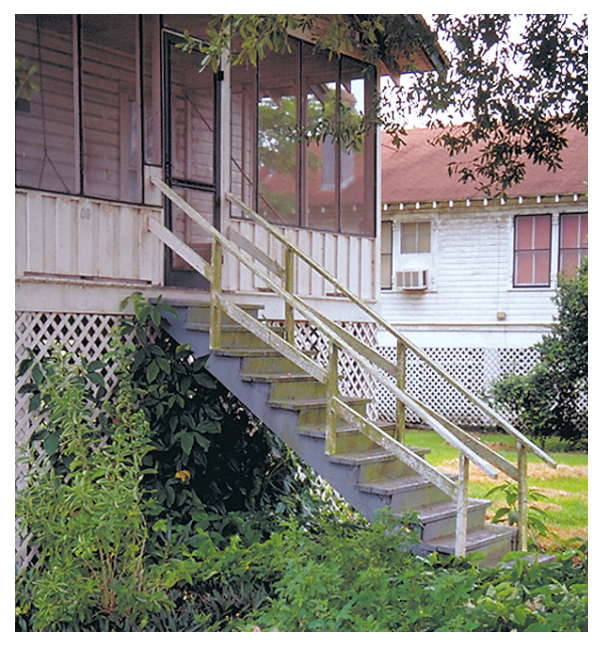

Figure 7. This building at the Everglades Experiment Station was originally constructed at the land surface; latticework and stairs were added after substantial land subsidence.
Delta of California and the Florida Everglades - continuing organic-soil subsidence threatens agricultural production, affects engineering infrastructure that transfers water supplies to large urban populations, and complicates ongoing ecosystem-restoration efforts sponsored by the Federal and State governments. Subsidence-weakened levees increase the potential for flooding of Delta islands, which could in turn disrupt freshwater flows and threaten the integrity of the vast north-to-south watertransfer system in California. In the Everglades agricultural area, where the value of all agricultural crops is currently about \$750 million (Snyder and Davidson, 1994), agriculture as currently practiced has a finite life expectancy because of the ongoing subsidence (fig. 7).

\section{Collapsing Cavities}

The sudden and sometimes catastrophic subsidence associated with localized collapse of subsurface cavities (sinkholes) (fig. 8) is detailed in two case studies. This type of subsidence is commonly triggered by groundwater-level declines caused by pumping and by enhanced percolation of ground water. Collapse features tend to be associated with specific rock types, such as evaporites (salt, gypsum, and anhydrite) and carbonates (limestone and dolomite) (fig. 9). These rocks are susceptible to dissolution in water and the formation of cavities Salt and gypsum are much more soluble than limestone, the rock type most often associated with catastrophic sinkhole formation.

Evaporite rocks underlie about 35 to 40 percent of the United States, though in many areas they are buried at great depths (Martinez and others, 1998). Natural solution-related subsidence has occurred in each of the major salt basins in the United States (Ege, 1984). The high solubilities of salt and gypsum permit cavities to form in days to years, whereas cavity formation in carbonate bedrock is a very slow process that generally occurs over centuries to millennia. Human activities can expedite cavity formation in these susceptible materials and trigger their collapse, as well as the collapse of preexisting subsurface cavities. Though the collapse features tend to be highly localized, their impacts can extend beyond the collapse zone via the potential introduction of contaminants to the ground-water system. Two cavity-collapse case studies - Retsof, New York, and west-central Floridadocument human-induced cavity collapses in salt and limestone, respectively.

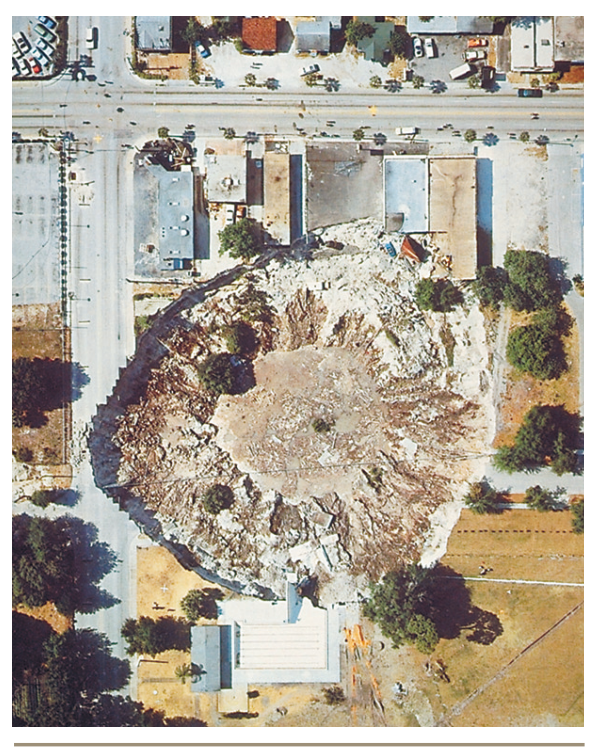

Figure 8. Collapse sinkholes, such as this one in Winter Park, Florida (1981), may develop abruptly (over a period of hours) and cause catastrophic damage.

\section{The Role of Science}

The occurrence of land subsidence is seldom as obvious as it is in the case of catastrophic sinkholes or mine collapses. Where ground-water mining or drainage of organic soils are involved, the subsidence is typically gradual and widespread, and its discovery becomes an exercise in detection. Gazing out over the San Joaquin Valley, California today, one would be hard-pressed to recognize that fewer than 75 years ago the land surface was nearly 30 feet higher in some locations (fig. 2). Subsidence detec- 


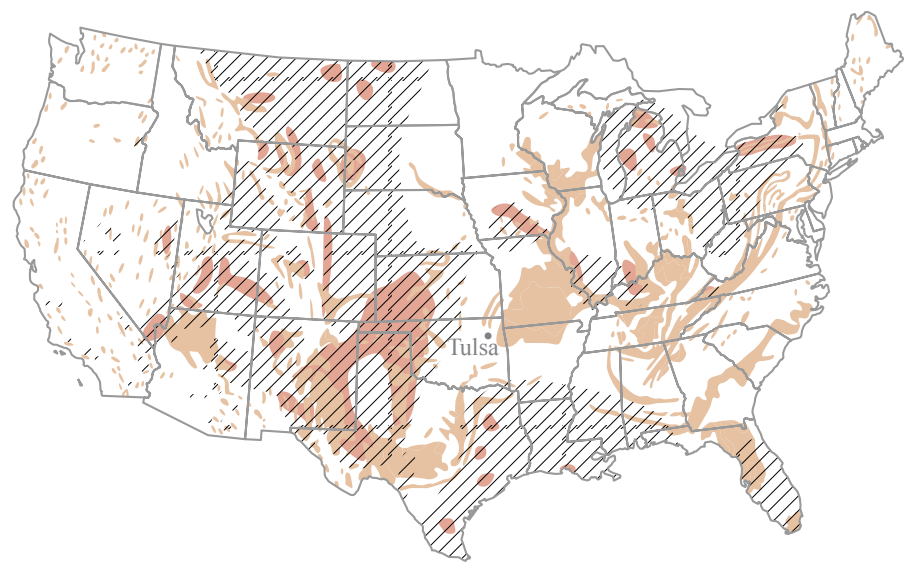

Figure 9. Salt and gypsum underlie about 40 percent of the contiguous United States. Carbonate karst landscapes constitute about 40 percent of the United States east of Tulsa, Oklahoma (White and others, 1995). tion and mapping programs are critical to the scientific understanding and management of our land and water resources.

The detection of regional-scale subsidence has historically depended on the discovery that key bench marks have moved.

\section{Figure 10. This InSAR-derived surface-defor- mation map shows subsidence in the Las Vegas Valley between April 1992 and December 1997 (Amelung and others, 1999). The subsidence is caused by aquifer-system compaction and controlled in part by surface faults, which have also been the focal point of earth-fissure for- mation.}

Land surveys establish bench-mark positions to accurately locate roadways, flood and drainage-control structures, pipelines, and other engineered infrastructure. Once unstable bench marks are discovered, and truly stable bench marks

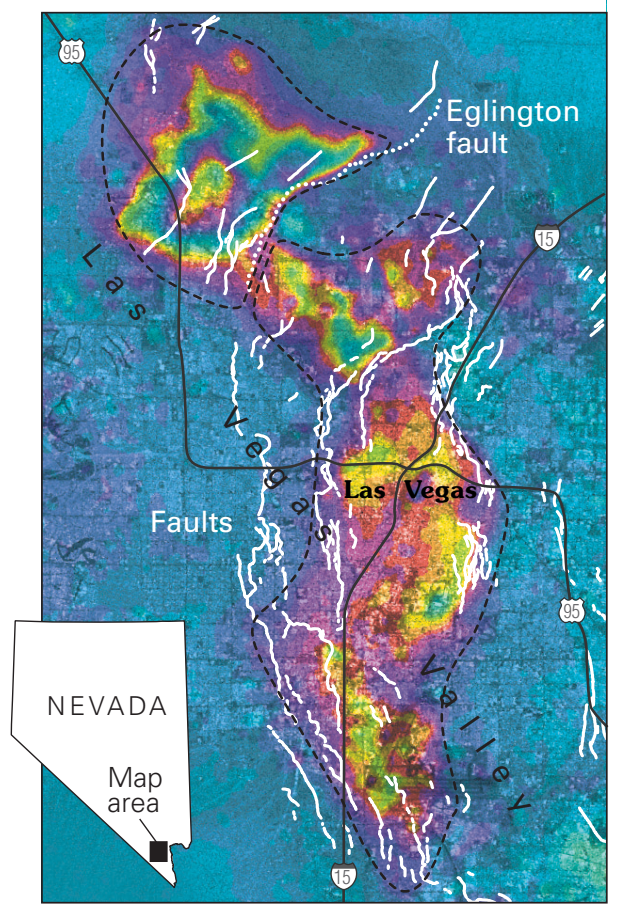

have been established, subsidence can be mapped. This has traditionally been accomplished using spirit leveling and, more recently, Global Positioning System (GPS) surveys. A new tool has emerged in the past decade that has dramatically improved our capability to detect and map land-surface deformation. This tool, interferometric synthetic aperture radar (InSAR), uses repeat-pass radar images from Earth-orbiting satellites to measure subsidence and uplift at unprecedented levels of spatial detail $(80 \mathrm{~m} \times 80 \mathrm{~m})$ and measurement resolution (sub-centimeter) (Galloway and others, 2000) (fig. 10).

Once subsidence is identified and mapped, subsidence-monitoring programs can be implemented and scientific studies can be launched to improve our understanding of the subsidence processes. A combination of scientific understanding and careful management can minimize the subsidence that results from developing our land and water resources.

—D.L. Galloway, D.R. Jones, S.E. Ingebritsen

\section{REFERENCES}

Amelung, F., Galloway, D.L., Bell, J.W., Zebker, H.A., and Laczniak, R.J., 1999, Sensing the ups and downs of Las Vegas-InSAR reveals structural control of land subsidence and aquifer-system deformation: Geology, v. 27, p. 483-486.

Clawges, R. M., and Price, C. V., 1999, Digital data sets describing principal aquifers, surficial geology, and ground-water regions of the conterminous United States: U.S. Geological Survey OpenFile Report 99-77 [accessed Sept. 17, 1999 at URL http://water.usgs.gov/pubs/ofr/ofr99-77].

Davies, W.E., and Legrand, H.E., 1972, Karst of the United States, in Herak, M., and Stringfield, V.T., eds., Karst-Important karst regions of the northern hemisphere, p. 467-505.

Ege, J.R., 1984, Mechanisms of surface subsidence resulting from solution extraction of salt, in Holzer, T.L., ed., Man-induced land subsidence: Geological Society of America Reviews in Engineering Geology, v. 6, p. 203-221.
Galloway, D.L., Jones, D.R., and Ingebritsen, S.E., 1999, Land subsidence in the United States: U.S. Geological Survey Circular 1182, 175 p.

Galloway, D.L., Jones, D.R., and Ingebritsen, S.E., 2000, Measuring land subsidence from space: U.S. Geological Survey Fact Sheet 051-00, 4 p.

Lucas, R.E., 1982, Organic soils (Histosols)_Formation, distribution, physical and chemical properties and management for crop production: Michigan State University Farm Science Research Report 435, 77 p.

Martinez, J.D., Johnson, K.S., and Neal, J.T., 1998, Sinkholes in evaporite rocks: American Scientist, v. 86 , p. 38-51.

National Research Council, 1991, Mitigating losses from land subsidence in the United States: Washington, D. C., National Academy Press, 58 p.

Snyder, G.H., and Davidson, J.M., 1994, Everglades agriculture: Past, present, and future, in Davis, S.M. and Ogden, J.C., The Everglades-The ecosystem and its restoration: Delray Beach, Fla., St. Lucie Press, p. 85-115.

Stephens, J.C., Allen, L.H., Jr., and Chen, Ellen, 1984 , Organic soil subsidence, in Holzer, T.L., ed., Maninduced land subsidence: Geological Society of America Reviews in Engineering Geology, v. 6, p. 107-122.

White, W.B., Culver, D.C., Herman, J.S., Kane, T.C., and Mylroie, J.E., 1995, Karst lands: American Scientist, v. 83, p. 450-459.

For more information on ground-water-resource issues and subsidence, please contact:

Chief, Office of Ground Water

U.S. Geological Survey

411 National Center

12201 Sunrise Valley Drive Reston, VA 20192

(703) 648-5001

http://water.usgs.gov/ogw 